\title{
PENINGKATAN PENGETAHUAN, SIKAP, DAN KETERAMPILAN IBU-IBU PKK DESA MAKAMHAJI MENGENAI PENANGGULANGAN PENYAKIT DEMAM BERDARAH DENGUE (DBD).
}

\author{
Arif Widodo \\ Jurusan Keperawatan - Fakultas Ilmu Kedokteran \\ Universitas Muhammadiyah Surakarta
}

\section{ABSTRACT}

Blood Fever Dengue is one of the contagious diseases which may cause death. The existence of the endemic area is one indicator of the failure in fighting against such disease. One of the main efforts which has high level of success is the efforts to eliminate the mosquito nest. Every year in Makam Haji Kartasura, it often appears some victims of such disease. The illumination about the eliminating of the mosquito nest to prevent the spread of Blood Fever Dengue in the Hall of Makam Haji shows a significant result. The "PKK" participants who previously have no idea about the cause, contamination, and the elimination of mosquito nest turn to have full knowledge about it. After having full understanding about it, they become aware of the way how to avoid and combat these Aides Aegepty mosquitoes. This illumination program is along with the model of applied prevention of such disease like the correct way to clean the bath tub, the way to have healthy household condition, the burial of second hands which may result water filling it, and how to care for the victims of such disease.

Kata kunci: aedes aegypti, demam berdarah, pendidikan kesehatan

\section{PENDAHULUAN}

Penyakit Demam Berdarah Dengue (DBD) atau Haemorraghic Fever merupakan suatu penyakit menular yang masih menjadi masalah kesehatan di hampir seluruh propinsi di Indonesia. Hal ini disebabkan, penyakit tersebut penyebarannya sangat cepat dan sering menimbulkan kejadian luar biasa / wabah, sehingga menyebabkan banyak penderita yang sakit bahkan sampai meninggal.

10 WARTA, Vol 10, No. 1, Maret 2007: 10 - 18 
Di Indonesia, DBD pertama kali dicurigai di Surabaya pada tahun 1968, tetapi konfirmasi virologis baru diperoleh pada tahun 1970. Di Jakarta, kasus pertama dilaporkan pada tahun 1969. Kemudian DBD berturut-turut dilaporkan di Bandung dan Jogjakarta (1972). Di luar jawa, penyakit DBD muncul pertama kali di Sumatera Barat, dan Lampung (1972), disusul oleh Riau, Sulawesi Utara dan Bali (1973). Pada tahun 1974, epidemi dilaporkan di Kalimantan Selatan dan Nusa Tenggara Barat. Pada tahun 1994 DBD telah menyebar ke seluruh Propinsi di Indonesia (FKUI, 2002).

Di Indonesia, dari waktu ke waktu penyakit DBD cenderung meningkat jumlah penderitanya dan semakin menyebar luas. Angka kesakitan DBD secara nasional adalah 18,25 per 10.000 penduduk dengan kamatian sebesar 2,5 per 10.000 penduduk. Di Jawa Tengah, setiap tahunnya kasus DBD terus meningkat secara fluktuatif, baik perkotaan maupun pedesaan. Di desa Makamhaji Kecamatan Kartasura. hampir dipastikan ada warga yang menderita DBD setiap tahunnya. Pada tahun 2005 Tercatat 3 orang telah terjangkit penyakit DBD di pondok Pesantren Muhammadiyah Hajjah Nuriah Shabran, 1 orang di kampung Kuyudan, dan 1 orang di kampung Windan yang terletak di desa Makamhaji. Pada bulan April 2006 terdapat 2 orang penderita DBD di kampung Sanggrahan, 6 orang di kampung Sidomulyo, dan pada bulan Mei 2006 terdapat 4 orang penderita DBD di perumahan dosen UMS, kampung Kuyudan Baru, Makamhaji.

Ibu-ibu yang aktif Pemberdayaan dan Kesejahteraan Keluarga (PKK) Makamhaji merupakan, perwakilan dari beberapa Rukun Tetangga (RT) yang ada di desa Makamhaji. Mereka perlu diberikan pengetahuan mengenai cara pemberantasan nyamukAedes Aegypti. Dengan pengetahuan dan pemahaman mengenai seluk beluk penyakit DBD, diharapkan mereka dapat menjadi motivator untuk upaya pemberantasan nyamuk Aedes Aegypti sebagai penyebab DBD di wilayah desa Makamhaji.

Jurusan keperawatan Fakultas Ilmu Kedokteran (FIK) UMS sebagai institusi pendidikan kesehatan merasa terpanggil untuk melaksanakan Pengabdian masyarakat. Pengabdian masyarakat yang akan dilakukan ini mempunyai tujuan meningkatkan pengetahuan, sikap, dan ketrampilan ibuibu PKK desa Makamhaji tentang penyakit DBD, yang meliputi pengertian penyakit DBD, penyebab, tanda-tanda penderita, cara penularan, akibat, pertolongan pada penderita, dan pencegahan penyakit DBD serta pemberantasan vektor DBD (nyamuk Aedes Aegypti).

Peningkatan Pengetahuan ... (Arif Widodo) 11 
Gerakan Pemberdayaan dan Kesejahteraan Keluarga (PKK) merupakan gerakan Nasional yang tumbuh dari, oleh, dan untuk masyarakat. Ibu-ibu PKK di desa Makamhaji merupakan sekumpulan ibu-ibu yang aktif dalam setiap kegiatan dan juga termasuk kader kesehatan. Kader kesehatan adalah siapa saja dari anggota masyarakat yang mau bekerja sama secara suka rela dan ikhlas, mau dan sanggup melaksanakan UPGK (Upaya Perbaikan Gizi Keluarga), mau dan sanggup menggerakkan masyarakat untuk melaksanakan kegiatan posyandu. Selain itu kader juga merupakan penggerak dalam masyarakat khususnya dalam membantu atau mendukung keberhasilan pemerintah di bidang kesehatan, yang tidak mengharapkan imbalan berupa gaji pemerintah melainkan bekerja secara sukarela.

Permasalahan utama penyakit DBD secara umum adalah bahwa 2,5 sampai 3 milyar orang berisiko terserang penyakit ini, Aedes aegypti adalah vektor epidemi utama, penyebaran penyakit mulai menyerang daerah pinggiran/pedesaan, diperkirakan terdapat 50 sampai 100 juta kasus per tahun, 500.000 kasus menuntut perawatan di Rumah Sakit, dan $90 \%$ menyerang anak-anak dibawah 15 tahun, rata-rata angka kematian (Case Fatality Ratel CFR ) mencapai $5 \%$, secara epidemis bersifat siklis (terulang pada jangka waktu tertentu), dan belum ditemukan vaksin pencegahnya (Depkes RI, 2000).

Penyakit DBD merupakan salah satu masalah kesehatan di Indonesia, hal ini tampak dari kenyataan yang ada, bahwa seluruh wilayah di Indonesia mempunyai risiko untuk terjangkit penyakit DBD, sebab baik virus penyebab maupun nyamuk penularnya sudah tersebar luas di perumahan penduduk maupun fasilitas umum diseluruh Indonesia. Laporan yang ada sampai saat ini penyakit DBD sudah menjadi masalah yang endemis pada 122 daerah tingkat II, 605 daerah kecamatan dan 1800 desa/kelurahan di Indonesia. Walaupun angka kesakitan penyakit ini cenderung meningkat dari tahun ke tahun, sebaliknya angka kematian cenderung menurun, dimana pada akhir tahun 60an/awal tahun 70-an sebesar 41,3\% menjadi berkisar antara 3-5\% pada saat sekarang (Darwowandono, 2004).

Strategi Upaya Pemberantasan Vektor DBD adalah sebagai berikut:

1. Penanggulangan nyamuk secara selektif dan terpadu yang dilakukan bersama-sama dengan masyarakat serta melibatkan partisipasi lembaga intersektoral.

2. Pengamatan penyakit dilakukan secara aktif dengan didukung oleh sistem informasi kesehatan yang efektif

3. Kesiapan menghadapai keadaan darurat

4 . Peniminkatank ketranmpitantuanr petatihtranr

12 WARTA, Vol 10, No. 1, Maret 2007: 10 - 18 


\section{Riset mengenai penanggulangan vektor (Depkes RI, 2000)}

Faktor-faktor Penyebab Munculnya Kembali WabahDBD adalah sebagai berikut: 1) pertumbuhan jumlah penduduk yang tidak memiliki pola tertentu; 2) urbanisasi yang tidak terencana dan terkontrol; 3) sistem pengelolaan limbah dan penyediaan air bersih yang tidak memadai; 4) berkembangnya penyebaran dan kepadatan nyamuk-nyamuk; 5) kurangnya sistem pengamatan nyamuk yang efektif; 6) meningkatnya pergerakan dan penyebaran virus dengu; 7) perkembangan hiperendemisitas; dan 8) melemahnya infrastrukturkesehatan masyarakat.

Penatalaksanaan DBD, adalah sebagai berikut: 1) istirahat di tempat tidur dianjurkan selama fase demam;2) obat anti piretik atau pengompresan diperlukan untuk menjaga suhu tubuh dibawah $40^{\circ} \mathrm{C} ; 3$ ) mungkin perlu diberikan obat analgesik atau obat sedatif ringan apabila pasien sangat kesakitan; 4) direkomendasikan untuk memberikan cairan dan elektrolit oral bagi pasien yang berkeringat atau muntah berlebihan; dan 5) untuk daerah endemis DBD, pasien harus di monitor sampai tidak demam dan setelah jumlah trombosit serta hematokrit dipastikan telah normal kembali.

\section{Tindakan Pencegahan dan Pemberantasan adalah sebagai berikut:}

Belum ada vaksin untuk pencegahan penyakit DBD dan belum ada obat-obatan khusus untuk penyembuhannya, dengan demikian pengendalian DBD tergantung pada pemberantasan nyamuk Aedes aegypti. Program pemberantasan penyakit DBD di berbagai negara umumya belum berhasil, karena masih tergantung pada penyemprotan insektisida untuk membunuh nyamuk dewasa. Penyemprotan membutuhkan pengoperasian yang khusus dan membutuhkan biaya yang tinggi.

Tindakan pencegahan dan pemberantasan akan lebih lestari bila dilakukan dengan pemberantasan sumber larva, untuk itu dibutuhkan kerjasama dengan sektor non kesehatan, seperti swasta dan kelompok masyarakat untuk memastikan pemahaman dan keterlibatan mereka dalam pelaksanaannya. Dalam hal ini perlu pendekatan yang terpadu terhadap pengendalian nyamuk dengan menggunakan semua metode yang tepat (lingkungan, biologi dan kimiawi) yang murah, aman dan ramah lingkungan. Upaya-upaya ini antara lain dengan pengelolaan lingkungan, perlindungan diri, pengendalian biologis dan pengendalian secara kimia.

Pengelolaan lingkungan ditujukan pada perubahan lingkungan, pemanfaataan lingkungan dan perubahan perilaku dan tempat tinggal manusia sehingga dapat mengurangikontak antara vektor dengan manusia. Metode yang digunakan Peningkatan Pengetahuan ... (Arif Widodo) 13 
antara lain perubahan habitat fisik vektor, pengelolaan wadah yang penting dan tidak penting pengelolaan dan pemindahan tempat perkembangbiakan alami, pemberantasan sarang nyamuk, pengelolaan sampah padat, mengeringkan instalasi penampungan air, mengisi lubang pagar, pembuangan ban bekas, botol dan kaleng bekas.

Perlindungan diri dilakukan dengan mengenakan pakaian pelindung, obat nyamuk, tirai dan kelambu. Pengendalian biologis dengan memelihara ikan pada tempat penampungan air. Sedangkan pengendalian kimia seperti penaburan bubuk abate pada tempat-tempat penampungan air efektif dilakukan tetapi memakan biaya yang cukup mahal, untuk pengasapan (fogging) akhir-akhir ini ada rekomendasi terbaru bahwa fogging sebaiknya tidak digunakan kecuali dalam keadaan genting selama terjadi wabah atau KLB DBD (Depkes RI, 2000).

Seperti tertulis sebelumnya bahwa pengendalian DBD dengan cara kimia kurang direkomendasikan karena selain membutuhkan pengoperasian secara khusus juga membutuhkan biaya yang mahal, maka pencegahan dan pemberantasan DBD lebih akan lestari dan berkesinambungan bila dilakukan dengan pengelolaan lingkungan. Untuk mengupayakan perubahan pengetahuan dan persepsi masyarakat mengenai penanggulangan DBD maka perlu dilakukan pelatihan yang terkait dengan hal tersebut. Bila pengetahuan dan persepsi masyarakat tentang segala sesuatu yang terkait denan dengan DBD dapat diluruskan, maka diharapkan pengendalian DBD yang secara lestari dengan mengoptimalkan partisipasi masyarakat dapat terwujud. Dengan demikian diharapkan masyarakat secara sadar dan mandiri dapat melakukan tindakantindakan pencegahan secara berkesinambungan tanpa ada unsur pemaksaan. Misalnya saja dengan melakukan pemantauan jentik secara berkala pada rumah masing-masing, agar perkembangbiakan nyamuk dapat terkendali.

\section{METODE KEGIATAN}

Metode yang akan digunakan pada kegiatan pengabdian masyarakat ini adalah berbentuk penyuluhan dengan metode ceramah, diskusi yang diikuti oleh 46 ibu-ibu PKK yang tinggal di desa Makamhaji. Materi ceramah yang diberikan menggunakan buku modul dan LCD. Topik yang akan didiskuskan adalah mengenai masalah DBD, cara penularan, pencegahan serta

14 WARTA, Vol 10, No. 1, Maret 2007: 10 - 18 
penanggulangan penyakit DBD dalam rangka pemberantasan nyamuk Aedes aegypti dengan pengasapan / foging.

Pelaksanaan kegiatan pengabdian masyarakat berupa ceramah dan diskusi ini dilaksanakan pada hari Selasa, 20 Juni 2006, bertempat di balai desa Makamhaji. Pelaksanaan pengabdian masyarakat ini dihadiri oleh 46 ibu-ibu yang mewakili seluruh Rukun Tetangga (RT) di Makamhaji, berlangsung dari jam 15.30 - 17.00.

\section{HASIL DAN PEMBAHASAN}

Secara umum, semangat para ibu-ibu PKK Makamhaji dalam menerima informasi kesehatan sangat baik. Hal ini dapat diketahui dari adanya peningkatan pengetahuan, sikap, dan ketrampilan para ibu-ibu PKK. Alat ukur berupa 20 pertanyaan pengetahuan mengenai cara-cara mencegah dan memberantas penyakit DBD, menangani atau mengobati penderita DBD serta pengetahuan mengenai siklus hidup naymukDBD. Sedangkan 20 pertanyaan mengenai sikap adalah berupa sikap terhadap penyuluhan kesehatan, dan 4 langkah dalam menangani DBD serta sikap dalam penanganan anggota keluarga yang menderita DBD.

Ibu-ibu PKK sebagai kader kesehatan di desa Makamhaji banyak yang mengajukan pertanyaan seputar masalah penyakit DBD. Pertanyaan yang diajukan diantaranya :

1. Mengapa penyakit demam berdarah sering muncul pada saat pergantian musim?

2. Apakah nyamuk DBD hanya berkembang biak di air yang jernih?

3. Bagaimana gejala-gejala orang yang terkena DBD?

4. Bagaimana memberantas serta membersihkan tempat perindukan nyamuk dan memberantas nyamuk yang tepat.

Setelah pertanyaan-pertanyaan dijawab oleh penceramah dengan jelas, kemudian dilakukan evaluasi dengan memberikan pertanyaan kembali tentang semua hal yang telah diceramahkan. Hasilnya ibu-ibu PKK dapat menjawab dengan benar. Hal ini menggambarkan bahwa pengetahuan yang diberikan telah dipahami oleh ibu-ibu PKK desa Makamhaji.

Evaluasi hasil kegiatan secara objektif dapat dilihat dari peningkatan nilai pengetahuan, sikap, dan ketrampilan yang diukur sebelum (pretes) dan postes (sesudah). Pretes dilakukan pada tanggal 20 Juni 2006, sedangkan postes dilakukan 3 hari setelah pemberian pelatihan, hal ini dikarenakan agar

Peningkatan Pengetahuan ... (Arif Widodo) 15 
peserta pelatihan ada kesempatan untuk membaca modul mengenai caracara penanganan dan pencegahan DBD yang diberikan ketika ceramah.

Beberapa pertanyaan pengetahuan dan sikap yang pada saat pretes masih salah atau mempunyai sikap yang kurang baik, namun setelah diberikan ceramah dan pemberian modul hasilnya adalah sebagai berikut:

\begin{tabular}{|c|c|}
\hline $\begin{array}{c}\text { PERTANYAAN } \\
\text { PENGETAHUAN/SIKAP }\end{array}$ & JAWABAN POSTES (yang benar) \\
\hline $\begin{array}{l}\text { Penyakit demam berdarah } \\
\text { hanya menyerang anak-anak }\end{array}$ & $\begin{array}{l}\text { Penyakit DBD dapat menyerang semua orang, } \\
\text { bisa anak-anak maupun dewasa. }\end{array}$ \\
\hline $\begin{array}{l}\text { Penularan penyakit demam } \\
\text { berdarah banyak terjadi } \\
\text { pada musim kemarau. }\end{array}$ & $\begin{array}{l}\text { Kepadatan nyamuk akan meningkat pada waktu } \\
\text { musim hujan, dimana terdapat genangan air } \\
\text { bersih yang dapat menjadi tempat berkembang } \\
\text { biaknya nyamuk aedes aegypti. }\end{array}$ \\
\hline $\begin{array}{l}\text { Jangkauan terbang nyamuk } \\
\text { demam berdarah adalah } 500 \\
\text { meter. }\end{array}$ & $\begin{array}{l}\text { Nyamuk DBD hanya terbang dengan jangkauan } \\
40-100 \text { meter. }\end{array}$ \\
\hline $\begin{array}{l}\text { Memberikan abate pada } \\
\text { penampungan air yang tidak } \\
\text { dapat dikuras adalah } \\
\text { pemborosan }\end{array}$ & $\begin{array}{l}\text { Bak-bak penampungan seperti tower yang susah } \\
\text { dikuras tiap minggu dapat diberi abate tiap } 2 \\
\text { bulan sekali. }\end{array}$ \\
\hline
\end{tabular}

Penyuluhan dengan metode ceramah dilakukan sebagai upaya / kegiatan untuk menyertai pelaksanaan pembrantasan nyamuk aedes aegypti dengan metode foging. Karena pada dasarnya peningkatan pengetahuan lebih baik daripada sekedarmelakukan kegiatan pemberantasan nyamuk tanpa pengetahuan yang benar, apa tujuan, manfaat, serta bahaya atau efek samping yang timbul. Pengetahuan yang baik akan merubah perilaku kesehatan seseorang. Pengetahuan yang diberikan terhadap ibu-ibu PKK di desa Makamhaji pada prinsipnya adalah menanamkan perilaku hidup yang sehat untuk menjaga lingkungan dalam rangka menanggulangi dan mencegah munculnya penyakit DBD. Pengetahuan yang diberikan juga tentang apa yang harus kita lakukan seharihari dalam mencegah penularan penyakit DBD, serta apa yang harus dilakukan saat pelaksanaan fogging untuk memberantas nyamuk dewasa.

\section{SIMPULAN DAN SARAN}

Pengetahuan, sikap, dan ketrampilan ibu-ibu PKK desa Makamhaji mengenai penanggulangan penyakit DBD adalah sangat diperlukan. Hal ini

16 WARTA, Vol 10, No. 1, Maret 2007: 10 - 18 
dapat dilihat dari adanya beberapa pertanyaan pretes yang masih salah. Beberapa pertanyaan pada saat pretes yang dijawab salah adalah : 1) Penyakit DBD dapat menyerang semua orang, bisa anak-anak maupun dewasa, 2) Kepadatan nyamuk akan meningkat pada waktu musim hujan, dimana terdapat genangan air bersih yang dapat menjadi tempat berkembang biaknya nyamuk aedes aegypti. 3 ) Nyamuk DBD hanya terbang dengan jangkauan 40 - 100 meter. 4) Bak-bak penampungan seperti tower yang susah dikuras tiap minggu dapat diberi abate tiap 2 bulan sekali.

Setelah dilakukan penyuluhan kesehatan mengenai penanggulangan penyakit DBD, pengetahuan, sikap, dan ketrampilan ibu-ibu PKK desa Makamhaji menjadi lebih baik. Masyarakat disarankan melaksanakan PSN secara bergotong royong di lingkungannya dan terbiasa melakukan 3M (menguras, menutup, dan mengubur). Jika memungkinkan dilakukan survei jentik oleh ibu-ibu PKK atau remaja pada masa-masa rawan DBD, yaitu menjelang selama musim hujan, serta menjelang musim kemarau.

\section{UCAPAN TERIMAKASIH}

Dalam pelaksanaan kegiatan pengabdian masyarakat ini kami tidak lepas dari bantuan dan bimbingan beberapa pihak. Ucapan terimaksaih kami sampaikan kepada Bapak Rektor melalaui Lembaga Pengabdian Masyarakat yang telah membiayai sehinga kegiatan ini dapat berjalan dengan baik. Terima kasih kepada Dekan FIK yang ikut memperlancar kegiatan ini. Ucapan terima kasih pula kami sampaikan kepada kepala desa Makamhaji yang telah memberikan ijin lokasi bagi pelaksanaan kegiatan pengadian masyarakat ini, serta semua ibu-ibu PKK Makamhaji yang telah berkenan meluangkan waktu untuk mendukung kegiatan ini.

\section{DAFTAR PUSTAKA}

Anonim. 2004. Profil Kesehatan Kotamadia Surakarta tahun 2004. Dinas Kesehatan Kota Surakarta.

Darmowandowo, Widodo. 2004. "Demam Berdarah Dengue". Artikel Ilmiah. http/www. Ppmplp.depkes.go.id

Depkes RI. 1997. Profil Peran Serta masyarakat Dalam Pembangunan Kesehatan. Jakarta: Depkes RI. 
Depkes RI. 2000. Pedoman Penanggulangan Demam Berdarah Dengue. Jakarta: Depkes RI.

FKUI, 2002 Demam Berdarah Dengue - Naskah Lengkap Bagi Pelatih dalam Tatalaksana Kasus DBD. Jakarta: Balai Penerbit FKUI. 
20 WARTA, Vol 10, No. 1, Maret 2007: 10 - 18 